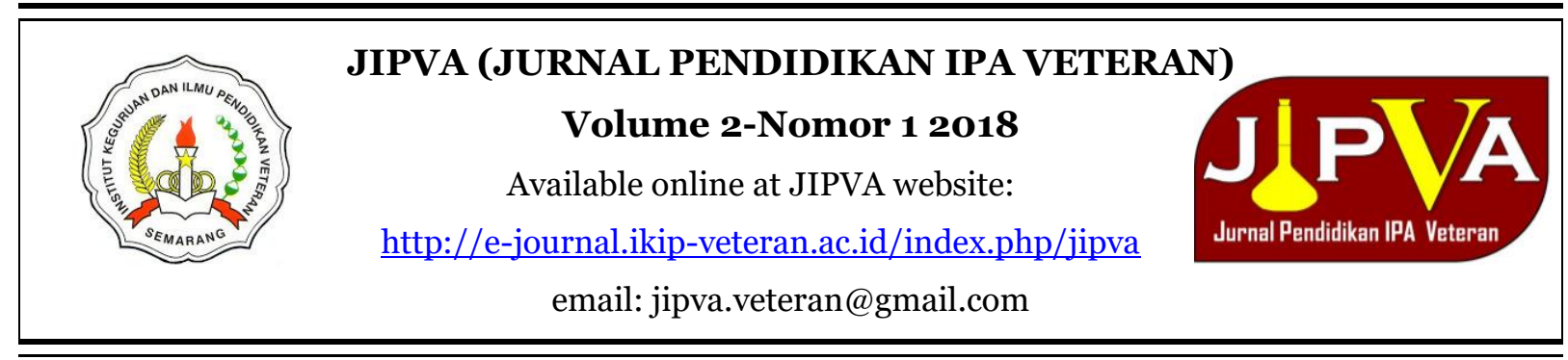

\title{
PENGARUH MODEL PEMBELAJARAN COOPERATIVE SCRIPT TERHADAP HASIL BELAJAR BIOLOGI DI KELAS VIII SMP 11 MANOKWARI
}

Yanto O. Rumbekwan ${ }^{1}$, Aksamina M. Yohanita ${ }^{2}$, Insar Damopolii ${ }^{3}$ *

${ }^{123}$ Jurusan Pendidikan Biologi, FKIP, Universitas Papua

*email: i.damopoli@unipa.ac.id

\begin{abstract}
Abstrak
Tujuan penelitian adalah untuk mengetahui perbedaan hasil belajar siswa yang diajarkan dengan model pembelajaran cooperative script dan model pembelajaran konvensional. Penelitian dilaksanakan di SMP 11 Manokwari. Jenis penelitian adalah kuasi eksperimen dengan menggunakan nonequivalent control group design. Sampel diambil dengan menggunakan purposive sampling dan diperoleh kelas VIII B (35 siswa) sebagai kelas kontrol dan kelas VIII C (35 siswa) sebagai kelas eksperimen. Analisis data menggunakan uji independent sample t-test. Hasil penelitian menunjukkan bahwa terdapat perbedaan yang signifikan antara nilai rata-rata posttest kelas eksperimen dan kelas kontrol dengan signifikan $0,000(\mathrm{P}<0,05)$. Rata-rata hasil belajar siswa kelas eksperimen yaitu sebesar 62,29 lebih tinggi dibandingkan dengan rata-rata hasil belajar siswa kelas kontrol yaitu sebesar 43,97.
\end{abstract}

Kata kunci: Model pembelajaran cooperative script, model pembelajaran konvensional, hasil belajar biologi

\section{THE EFFECT OF COOPERATIVE SCRIPT LEARNING MODEL ON BIOLOGY STUDENTS' ACHIEVEMENT IN CLASS VII SMP 11 MANOKWARI}

\begin{abstract}
The purpose of this study was to determine the difference of students' achievement who taught with cooperative script learning model and conventional learning model. The research was conducted at SMP 11 Manokwari. The research type is quasi-experimental used nonequivalent control group design. Samples were taken by using purposive sampling and obtained group VIII B (35 students) as the control group and group VIII C (35 students) as experiment group. We used independent sample $t$-test to analyze data. The results showed that there was a significant difference between the posttest mean score of the experimental and the control group with significant 0,000 ( $P<0.05)$. The mean student achievement of the experimental group was 62,29\% higher than the mean students' achievement of the control group was 43,97.
\end{abstract}

Keywords: Cooperative script learning model, conventional learning model, biology students' achievement.

\section{PENDAHULUAN}

Belajar adalah suatu proses yang terus dilakukan oleh manusia untuk mencapai tujuan yang diinginkan. Proses pendidikan yang terjadi pada satuan pendidikan merupakan kegiatan interaksi antar pendidik dengan siswa dengan tujuan terjadi perubahan pengetahuan, sikap dan karakter. Proses pembelajaran terjadi melalui interaksi dari berbagai komponen. 
Menurut Damopolii (2017) bahwa proses pembelajaran merupakan proses interaksi antar empat komponen sistem pembelajaran yaitu guru, siswa, materi belajar, dan lingkungan. Menurut Baransano et al. (2017) bahwa pembelajaran harus berpusat pada siswa.

Menurut Trianto (2011), berdasarkan hasil analisis penelitian terhadap rendahnya hasil belajar siswa disebabkan oleh dominannya proses belajar mengajar secara konvensional dan Werimon et al. (2017) menyatakan bahwa rendahnya proses pembelajaran yang diperoleh siswa merupakan salah satu masalah yang dihadapi oleh tenaga pendidik. Menurut Slameto (2013), pembelajaran dipengaruhi oleh dua faktor, yaitu (1) faktor internal berupa kemampuan awal siswa dan (2) faktor eksternal berupa pendekatan pembelajaran. Salah satu pendidikan formal yang ada di Manokwari yaitu SMP Negeri 11 Manokwari. SMP Negeri 11 Manokwari tentunya telah menghasilkan banyak sumber daya manusia yang sampai saat ini telah memiliki beragam profesi di berbagai bidang. Berdasarkan pengamatan di sekolah, Guru IPA masih menggunakan model pembelajaran yang bersifat konvensional, dan berpusat pada guru. Guru banyak menggunakan model pembelajaran konvensional berupa ceramah dan diskusi. Kegiatan pembelajaran seperti ini menyebabkan siswa kurang aktif dalam proses pembelajaran. Siswa terlihat cepat bosan dan membuat siswa kurang fokus terhadap isi materi pembelajaran yang disampaikan oleh guru. Hasil dari pembelajaran seperti ini yaitu masih banyak siswa yang belum mencapai hasil belajar sesuai dengan KKM 60. Oleh karena itu, Proses belajar mengajar dapat dilaksanakan dengan berbagai inovasi, seperti penggunaan model pembelajaran kooperatif. Menurut Damopolii et al. (2018) bahwa mengajar tidak ditentukan oleh selera guru, akan tetapi sangat ditentukan oleh siswa itu sendiri

Menurut Ibrahim (2000), unsurunsur pembelajaran kooperatif adalah (1) siswa dalam kelompoknya memiliki anggapan bahwa mereka "sehidup sepenanggungan bersama"; (2) siswa memiliki tanggung jawab terhadap semua yang terjadi dalam kelompoknya; (3) semua siswa dalam kelompoknya memiliki tujuan yang sama; (4) adanya kesamaan dalam pembagian tugas dan tanggung jawab di antara anggota kelompoknya; (5) kelompok siswa diberikan evaluasi dan diberikan penghargaan; (6) siswa berbagi kepemimpinan dan memperoleh keterampilan untuk saling bekerjasama; dan (7) siswa akan diminta mempertanggungjawabkan secara individual materi yang ditangani dalam kelompok koperatif.

Salah satu model pembelajaran kooperatif yang dapat digunakan dalam proses belajar mengajar adalah cooperative script. Menurut Arimadona (2017) bahwa pemilihan model pembelajaran yang tepat oleh guru sangat menentukan hasil belajar siswa. Penelitian Hestyana et al. (2013) menyarankan bahwa guru agar menggunakan model pembelajaran coperative script dalam kegiatan pembelajaran karena dapat meningkatkan hasil belajar siswa. Menurut Suprijono (2013), langkah-langkah dalam pembelajaran cooperative script yaitu: 1) Guru membagi siswa untuk saling berpasangan, 2) Membagikan materi kepada setiap siswa untuk dibaca dan membuat ringkasannya, 3) Guru dan siswa menetapkan siapa yang pertama berperan sebagai pembicara dan siapa yang berperan sebagai pendengar, 4) Pembicara 
menyampaikan ringkasannya selengkap mungkin kepada pendengar, dengan memasukkan ide-ide pokok dalam ringkasannya, sementara pendengar menyimak, bertanya, mengoreksi dan menunjukkan ide-ide pokok yang kurang lengkap, 5) Bertukar peran, semula sebagai pembicara ditukar menjadi pendengar dan sebaliknya, dan 6) Guru membantu siswa menyusun kesimpulan sesuai materi yang dipelajari.

Menurut Sharan (2012) cooperative Script menekankan pada proses pemahaman konsep melalui keterampilan berkomunikasi siswa, dengan demikian dominasi guru dalam pembelajaran dapat dikurangi melalui kegiatan siswa dalam langkah-langkah cooperative Script. Pembelajaran yang awalnya bersifat teacher center akan berubah menjadi student center. Model pembelajaran cooperative script efektif meningkatkan hasil belajar. Banyak hasil penelitian yang menyimpulkan bahwa terdapat pengaruh model pembelajaran cooperative script terhadap hasil belajar siswa, dimana siswa yang diajarkan dengan model pembelajaran cooperative script lebih tinggi hasil belajarnya dibandingkan dengan siswa diajarkan dengan model pembelajaran konvensional. (Hestyana, 2013; Suwardi et al., 2013; Armansyah, 2014; Indriani et al., 2015; Saragih dan Tarigan, 2016).

Menurut Chotimah dan Dwitasari (2009) bahwa beberapa kelebihan model pembelajaran cooperative script adalah melatih siswa menjadi pendengar, pembicara, dan teliti terhadap informasi yang ia peroleh. Keadaan proses pembelajaran yang selama ini dilaksanakan di sekolah yang membuat hasil belajar siswa menjadi rendah, berubah menjadi pembelajaran yang inovatif dengan adanya penggunaan model pembelajaran cooperative script untuk memperbaiki hasil belajar siswa menjadi lebih baik.

\section{METODE}

\section{Jenis Penelitian}

Penelitian ini merupakan penelitian kuasi eksperimen (eksperimen semu) dengan desain nonequivalent control group design.

Tabel 1. Nonequivalent Control Group Design

\begin{tabular}{ccc}
\hline Pretest & Perlakuan & Posttest \\
\hline $\mathrm{O}_{1}$ & $\mathrm{X}$ & $\mathrm{O}_{2}$ \\
$\mathrm{O}_{3}$ & & $\mathrm{O}_{4}$
\end{tabular}

Sugiyono, (2015)

Keterangan:

O1 : Pretest grup eksperimen

$\mathrm{O} 2$ : Posttest grup eksperimen

O3 : Pretest grup kontrol

O4 : Posttest grup kontrol

$\mathrm{X}$ : Perlakuan dengan penerapan model pembelajaran cooperative script

\section{Subjek Penelitian}

Populasi dalam penelitian ini adalah seluruh siswa kelas VIII SMP Negeri 11 Manokwari dengan jumlah siswa sebanyak 115 orang yang terbagi ke dalam 4 kelas. Sampel dalam penelitian ini ditentukan dengan teknik purposive sampling, yaitu pengambilan subjek bukan didasarkan atas strata, random atau daerah tetapi didasarkan atas adanya tujuan tertentu. Hal ini sesuai dengan penelitian kuasi eskperimen yang memilih sampel tidak secara random melainkan dengan memilih kelas yang sudah ada. Sampel diambil dari kelas VIII B (35 siswa) sebagai kelas kontrol dan kelas VIII C (35 siswa) sebagai kelas eksperimen 


\section{Prosedur}

Prosedur penelitian terbagi menjadi 3 tahap yaitu sebagai berikut:

\section{Tahap Persiapan}

1. Observasi awal

2. Studi literatur

3. Mempelajari kurikulum

4. Penentuan materi dan strategi pembelajaran

5. Penentuan sampel

6. Penyusunan instrumen penelitian

7. Uji coba instrumen penelitian

\section{Tahap Pelaksanaan}

1. Pemberian pretest kelas kontrol dan kelas eksperimen

2. Pemberian perlakuan (Kelas eksperimen diberi perlakuan dengan menggunakan model pembelajaran cooperative script dan kelas kontrol diajarkan dengan menggunakan mode pembelajaran konvensional)

3. Pemberian posttest Kelas Kontrol dan Kelas Eksperimen

\section{Tahap akhir}

1. Pengolahan data

2. Kesimpulan

3. Pembuatan laporan

\section{Teknik Analisis Data}

1. Uji Normalitas Data

Pada penelitian ini uji normalitas menggunakan uji Kolmogorov-Smirnov dan Shapiro-Wilk pada $\alpha=0,05$. Jika $\mathrm{P}>0,05$ maka data berdistribusi normal.

2. Uji Homogenitas Data

Uji homogenitas pada penelitian ini menggunakan uji Levene dengan pengujian homogenitas yaitu jika nilai Sig. > 0,05 maka data homogen.

3. Uji Hipotesis

Uji hipotesis dalam penelitian ini dilakukan untuk mengetahui adanya perbedaan signifikan pada hasil belajar biologi siswa. Uji hipotesis dalam penelitian ini menggunakan independent sample t-test (Uji t) dengan bantuan program SPSS 20 for Windows.

Pengujian secara statistik dirumuskan sebagai berikut :

$$
\begin{aligned}
& \mathrm{H}_{0}: \mu_{1}=\mu_{2} \\
& \left.\mathrm{H}_{1}: \mu_{1} \neq \mu_{2}\right)
\end{aligned}
$$

$\mathrm{H}_{0}$ : Tidak ada perbedaan hasil belajar siswa yang diajarkan dengan menggunakan model pembelajaran cooperative script dan model konvensional.

$\mathrm{H}_{1}$ : Ada perbedaan hasil belajar siswa yang diajarkan dengan menggunakan model pembelajaran cooperative script dan model konvensional.

$\mu_{1}$ : Rata-rata hasil belajar kelas eksperimen

$\mu_{2}$ : Rata-rata hasil belajar kelas kontrol

Kriteria pengujian:

1. Jika sig $\geq 0,05 \mathrm{~h}_{1}$ ditolak maka $\mathrm{h}_{0}$ diterima (tidak ada perbedaan).

2. Jika sig $<0,05 \mathrm{~h}_{1}$ diterima maka $\mathrm{h}_{0}$ ditolak (ada perbedaan).

\section{HASIL DAN PEMBAHASAN}

Hasil belajar siswa diperoleh berdasarkan tes kemampuan awal (pretest) dan tes kemampuan akhir (posttest) dalam penelitian ini disajikan dalam dua tahap yaitu pretest dan posttest sebagai berikut:

Tabel 2. Rata-Rata Hasil Belajar Kelas Eksperimen dan Kontrol

\begin{tabular}{ccc}
\hline Data & $\begin{array}{c}\text { Mean } \\
\text { Pretest }\end{array}$ & $\begin{array}{c}\text { Mean } \\
\text { Posttest } \\
\text { Eksperimen }\end{array}$ \\
Kontrol & 35,26 & 62,29 \\
Berdasarkan data pada & Tabel 2, \\
menunjukkan bahwa terdapat perbedaan \\
rata-rata hasil belajar siswa sebelum dan \\
sesudah perlakuan. Pada awal
\end{tabular}


pembelajaran, kemampuan awal siswa pada kelas kontrol lebih tinggi dibandingkan kemampuan awal siswa pada kelas eksperimen. Setelah diberikan perlakukan, kemampuan akhir siswa pada kelas eksperimen lebih tinggi dibandingkan kemampuan akhir siswa pada kelas kontrol). Grafik perbandingan kemampuan awal dan akhir ditampilkan pada Gambar 1 berikut:

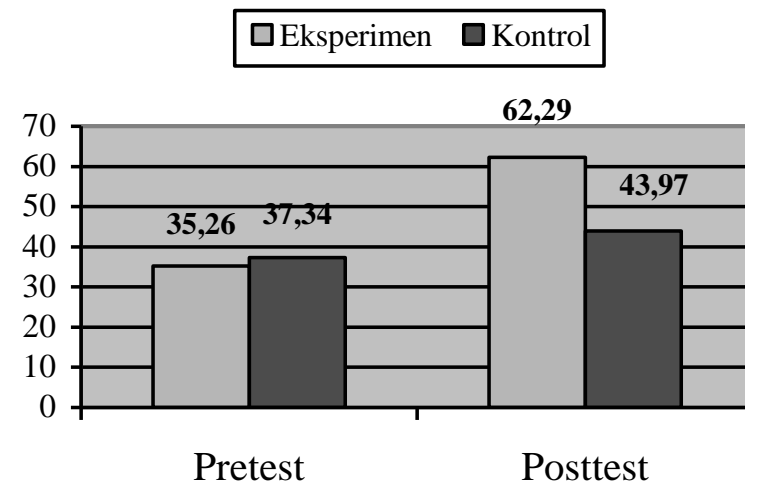

Gambar 1. Grafik Perbedaan Rata-Rata Hasil Belajar Kelas Eksperimen dan Kontrol

Tabel 3. Persentase Hasil Belajar Siswa Kelas Eksperimen

\begin{tabular}{cccc}
\hline Nilai & Keterangan & $\mathbf{f}$ & $\begin{array}{c}\mathbf{P}(\mathbf{f} / \mathbf{N} * \mathbf{1 0 0}) \\
(\boldsymbol{\%})\end{array}$ \\
\hline $80-100$ & Sangat Baik & 6 & 17,14 \\
$70-79$ & Baik & 3 & 8,57 \\
$60-69$ & Cukup & 14 & 40,00 \\
$40-59$ & Kurang & 12 & 34,29 \\
$0-39$ & Sangat Kurang & 0 & 0,00 \\
\hline \multicolumn{5}{c}{$\mathbf{N = 3 5}$} & $\mathbf{1 0 0 , 0 0}$ \\
\hline
\end{tabular}

Berdasarkan data pada Tabel 3, diperoleh bahwa persentase hasil belajar siswa kategori cukup sampai sangat baik sebesar $65,71 \%$, sedangkan kategori sangat kurang sampai kurang sebesar 34,29\%. Hal ini menunjukkan lebih dari $60 \%$ siswa memperoleh nilai yang cukup baik. Grafik presentasi hasil belajar siswa pada kelas eksperimen ditampilkan pada Gambar 2 berikut:

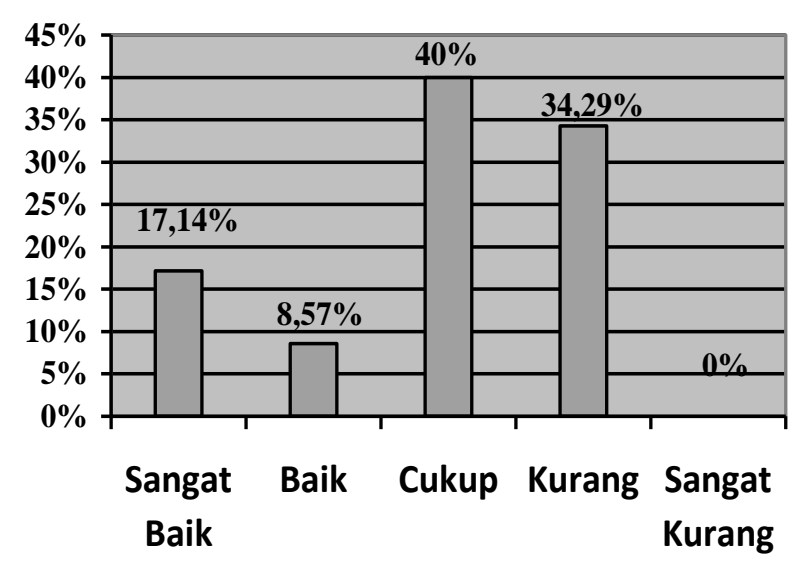

Gambar 2. Grafik Persentase Hasil Belajar Kelas Eksperimen

Tabel 4. Persentase Hasil Belajar Siswa Kelas Kontrol

\begin{tabular}{cccc}
\hline Nilai & Keterangan & $\mathbf{f}$ & $\begin{array}{c}\mathbf{P}(\mathbf{f} / \mathbf{N} * \mathbf{1 0 0}) \\
(\mathbf{\%})\end{array}$ \\
\hline $80-100$ & Sangat Baik & 0 & 0,00 \\
$70-79$ & Baik & 1 & 2,85 \\
$60-69$ & Cukup & 8 & 22,86 \\
$40-59$ & Kurang & 12 & 34,29 \\
$0-39$ & Sangat Kurang & 14 & 40,00 \\
\hline \multicolumn{2}{c}{$\mathbf{N = 3 5}$} & & $\mathbf{1 0 0 , 0 0}$ \\
\hline
\end{tabular}

Berdasarkan data pada Tabel 4, diperoleh bahwa persentase hasil belajar siswa kategori cukup - sangat baik sebesar $25,71 \%$, sedangkan kategori sangat kurang - sampai kurang sebesar 74,29\%. Hal ini menunjukkan kurang dari $60 \%$ siswa memperoleh nilai yang cukup baik. Grafik presentasi hasil belajar siswa pada kelas eksperimen ditampilkan pada Gambar 3 berikut: 


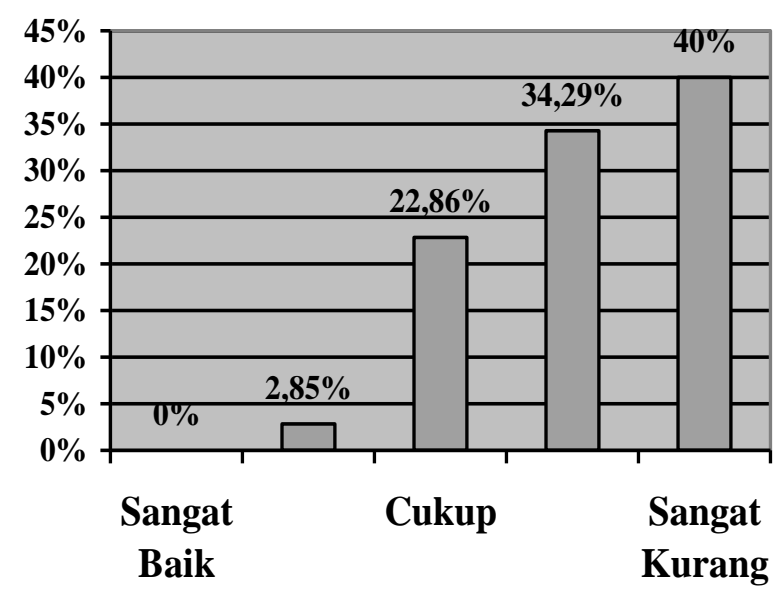

Gambar 3. Grafik Persentase Hasil Belajar

Kelas Eksperimen

Tabel 5. Hasil uji normalitas data pretest

\begin{tabular}{lcccc}
\hline Kelompok & df & Sig. & $\boldsymbol{\alpha}$ & Ket \\
\hline Eksperimen & 35 & 0117 & 0,05 & normal \\
Kontrol & 35 & 0,058 & 0,05 & normal \\
\hline
\end{tabular}

Berdasarkan Tabel 5, diperoleh bahwa nilai signifikan kelas eksperimen 0,117 dan nilai signifikan kelas kontrol 0,058. Data tersebut lebih besar dari taraf signifikan 0,05. Hal ini menunjukkan bahwa data pretest kelas eksperimen dan kontrol berdistribusi normal.

Tabel 6. Hasil Uji Homogenitas Data

\begin{tabular}{llllll}
\multicolumn{7}{c}{ Pretest } \\
\hline Data & $\mathbf{d f}_{\mathbf{1}}$ & $\mathbf{d f}_{\mathbf{2}}$ & Sig. & A & Ket. \\
\hline Pretest & 1 & 68 & 0,675 & 0,05 & Homogen \\
\hline
\end{tabular}

Berdasarkan data pada Tabel 6, diperoleh nilai signifikan kelas eksperimen dan kelas kontrol adalah 0,675. Hal ini menunjukkan bahwa nilai signifikan lebih besar dari 0,05, maka dikatakan bahwa data pretest kelas eksperimen dan kontrol adalah homogen).

Tabel 7. Hasil Uji Perbedaan Rata-Rata Pretest

\begin{tabular}{llllc}
\hline Data & Df & Sig. & A & Ket. \\
\hline Pretest & 68 & 0,555 & 0,05 & $\begin{array}{c}\text { Tidak ada } \\
\text { perbedaan }\end{array}$ \\
\hline
\end{tabular}

Berdasarkan pada Tabel 7, diperoleh nilai signifikan untuk pretest kelas eksperimen dan kontrol dengan yaitu 0,555 $(\mathrm{P}>0,05)$, maka dinyatakan tidak ada perbedaan rata-rata nilai kemampuan awal (pretest) kelas eksperimen dan kontrol. Menurut Werimon et al. (2017) bahwa perbedaan kemampuan awal siswa menentukan selanjutnya, yaitu jika kemampuan awal sama, maka tidak dilanjutkan analisis gain. Dalam penelitian ini kemampuan awal secara deskriptif berbeda, tetapi secara statistik tidak berbeda, sehingga tidak dilanjutkan dengan analisis gain.

Tabel 8. Hasil uji normalitas data posttest

\begin{tabular}{lcccc}
\hline \multicolumn{1}{c}{ Kelompok } & Df & Sig. & $\boldsymbol{\alpha}$ & Ket \\
\hline Eksperimen & 35 & 0160 & 0,05 & normal \\
Kontrol & 35 & 0,170 & 0,05 & normal \\
\hline
\end{tabular}

Berdasarkan Tabel 8, diperoleh bahwa nilai signifikan kelas eksperimen 0,160 dan nilai signifikan kelas kontrol 0,170. Data tersebut lebih besar dari taraf signifikan 0,05. Hal ini menunjukkan bahwa data posttest kelas eksperimen dan kontrol berdistribusi normal.

Tabel 9. Hasil Uji Homogenitas Data Posstest

\begin{tabular}{llllll}
\hline Data & df $_{\mathbf{1}}$ & $\mathbf{d f}_{\mathbf{2}}$ & Sig. & A & Ket. \\
\hline Posttest & 1 & 68 & 0,257 & 0,05 & Homogen \\
\hline
\end{tabular}

Berdasarkan pada Tabel 9, diperoleh nilai signifikan kelas eksperimen dan kelas kontrol adalah 0,257. Hal ini menunjukkan bahwa nilai signifikan lebih besar dari 0,05, maka dikatakan bahwa data posttest kelas eksperimen dan kontrol adalah homogen).

Tabel 10. Hasil uji perbedaan rata-rata

\begin{tabular}{lllll}
\multicolumn{5}{c}{ posttest } \\
\hline Data & df & Sig. & $\boldsymbol{\alpha}$ & Ket. \\
\hline Posttest & 68 & 0,000 & 0,05 & $\begin{array}{l}\text { Terdapat } \\
\text { perbedaan }\end{array}$ \\
\hline
\end{tabular}


Berdasarkan data pada Tabel 7, diperoleh nilai signifikan untuk pretest kelas eksperimen dan kontrol dengan yaitu $0,000(\mathrm{P}<0,05)$, maka dinyatakan terdapat perbedaan rata-rata nilai kemampuan akhir (posttest) kelas eksperimen dan kontrol.

Hasil penelitian menunjukkan bahwa hasil belajar siswa kelas eksperimen yaitu siswa yang diajarkan dengan model pembelajaran cooperative script berbeda dengan hasil belajar siswa pada kelas kontrol yaitu siswa yang diajarkan dengan model pembelajaran konvensional. Ratarata hasil belajar siswa kelas eksperimen sebesar 62,29 lebih tinggi dibandingkan dengan hasil belajar siswa kelas eksperimen yaitu sebesar 43,97. Hasil penelitian sejalan dengan penelitian yang telah dilakukan oleh Tiara et al. (2014), bahwa penerapan model pembelajaran cooperative script memiliki pengaruh yang positif dan signifikan terhadap hasil belajar siswa dan Penelitian Armansyah (2014) menemukan bahwa Hasil belajar siswa kelompok eksperimen pada mata pelajaran biologi dengan menggunakan pembelajaran konvensional mencapai nilai rata-rata yang dapat dikategorikan rendah dan hasil belajar siswa kelompok eksperimen pada mata pelajaran biologi dengan menggunakan pembelajaran kooperatif tipe cooperative script dapat mencapai nilai rata-rata yang dapat dikategorikan tinggi.

Model pembelajaran cooperative script merupakan salah satu model pembelajaran kooperatif yang membuat siswa menjadi lebih aktif dalam belajar. Model pembelajaran cooperative script yang digunakan dalam penelitian ini terdiri dari dua variasi. Variasi pertama adalah diskusi dua orang siswa yang diberi kode A dan B, dan variasi kedua adalah diskusi empat orang siswa yang diberi kode A, B, $\mathrm{C}$ dan $\mathrm{D}$.

Pada pembelajaran dengan model pembelajaran cooperative script variasi pertama, siswa mendapatkan lembar kerja siswa (LKS) berbeda yang diberi kode A dan kode B. Masing-masing siswa diminta mengerjakan tugas yang ada dalam LKS. Setelah siswa selesai mengerjakan tugas dalam LKS, siswa diminta untuk membacakan hasil kerjaannya kepada pasangannya secara bergantian. Disini terjadi interaksi antara siswa yang berperan sebagai pembicara mengutarakan hasilnya kerjanya, dan siswa sebagai pendengar mendengarkan hasil yang diutarakan oleh temannya.

Siswa yang berperan sebagai pendengar memberi masukan dan pertanyaan kepada pembicara. Menurut Tiara (2014) dalam pembelajaran menggunakan model pembelajaran cooperative script masing-masing siswa diberi peran dalam kelompoknya yaitu sebagai pembicara dan pendengar sehingga siswa yang suka mengobrol dengan temannya dapat diarahkan untuk membicarakan mengenai materi pelajaran yang sedang dibahas dan siswa menjadi lebih aktif karena jumlah anggota kelompok yang hanya 2 orang dan masingmasing siswa memiliki peran.

Pada variasi kedua, digunakan pola ABCD. Berbeda dengan pola $\mathrm{AB}$, pada pola ini terdapat empat orang siswa dalam satu kelompok. Pola penyajiannya dengan cara masing-masing siswa memperoleh LKS yang berbeda-beda. Setelah mereka mengerjakan LKS, siswa A akan menjadi pembicara dan siswa B, C dan D sebagai pendengar. Demikian seterusnya sampai siswa D menjadi pembicara dan siswa A, B dan $\mathrm{C}$ menjadi pendengar. Melalui 
pembicara, siswa yang berperan sebagai pendengar mendengarkan dengan sangat fokus karena pembicara terdiri dari 3 orang. Selain itu dengan adanya pembelajaran cooperatif script membuat siswa terlatih mengungkapkan kesalahan orang lain dengan lisan. Menurut Sharan (2012) bahwa sebagai teman berpasangan dalam kelompok, siswa dapat mempraktikkan keterampilanketerampilan mendengarkan. Mereka terlibat dalam pemecahan masalah dan menganalisis cara berpikir mereka sendiri, menerima umpan balik dan arahan teman.

Dalam pembelajaran menggunakan model pembelajaran cooperative script siswa bekerja dalam kelompok secara berdua atau berempat, dimana siswa secara bergantian membacakan hasil kerjanya kepada teman yang sebagai pendengar. Pembelajaran cooperative script memiliki perbedaan dengan metode pembelajaran yang lain yang dapat dilihat dari proses pembelajaran yang lebih menekankan kepada proses kerja sama dalam kelompok. Menurut Hanafiah dan Suhana (2010) bahwa cooperative script adalah model pembelajaran dimana siswa bekerja berpasangan dan secara lisan mengikhtisarkan bagian-bagian dari materi yang dipelajari. Tujuan yang ingin dicapai tidak hanya kemampuan siswa dalam penguasaan konsep materi yang diajarkan guru, tetapi juga adanya unsur kerja sama antar siswa untuk penguasaan materi yang dipelajari.

Perbedaan hasil belajar siswa antara siswa pada kelas eksperimen dan kontrol sejalan dengan penelitian yang telah dilakukan oleh Suryani et al. (2013) bahwa terdapat perbedaan hasil belajar yang signifikan antara siswa yang diajarkan dengan menggunakan model pembelajaran cooperative script dengan siswa yang diajarkan dengan menggunakan model pembelajaran konvensional. Perbedaan ini diakibatkan oleh pembelajaran konvensional yang masih bersifat teacher center, dimana guru memaikan peranan penting dan memegang kendali dalam proses belajar mengajar di dalam kelas. Menurut Muliawan et al. (2014) dan Munir et al. (2018) bahwa pembelajaran konvensional guru lebih banyak mendominasi kegiatan pembelajaran, sehingga bersifat teacher centered (berpusat pada guru).

Pembelajaran dengan menggunakan cooperative script membuat siswa menjadi lebih aktif dan termotivasi untuk belajar. Menurut Damopolii (2018) bahwa motivasi berhubungan dengan hasil belajar siswa. Pada penelitian yang telah dilaksanakan ditemukan bahwa penggunaaan model pembelajaran cooperative script yang membuat siswa termotivasi untuk belajar, menyebabkan hasil belajar siswa menjadi lebih baik. Hasil belajar yang baik menandakan guru berhasil dalam mengajarkan konsep materi kepada siswanya. Pada pembelaran dengan menggunakan model konvensional membuat siswa pasif dan tidak termotivasi untuk belajar, sehingga hasil belajar siswa menjadi lebih rendah atau tidak sesuai dengan harapan guru.

Manfaat dari penggunaan model pembelajaran cooperative script dalam penelitian ini adalah dapat mengurangi kesenjangan pendidikan khususnya dalam wujud input pada tingkat individual atau perorangan, karena dengan belajar dengan menggunakan pembelajaran kooperatif dapat menumbuhkan jiwa sosial dalam diri siswa dan mengembangkan solidaritas antar siswa. Siswa menjadi lebih terlatih dalam mendengar, berbicara, teliti. aktif 
dan mampu mengoreksi informasi ilmiah yang disampaikan oleh orang lain.

\section{SIMPULAN DAN SARAN}

\section{Simpulan}

Kesimpulan dalam penelitian ini adalah terdapat perbedaan hasil belajar siswa yang diajarkan dengan menggunakan model pembelajaran cooperative script dengan hasil belajar siswa yang diajarkan dengan menggunakan model pembelajaran konvensional. Rata-rata hasil belajar siswa pada pada kelas eksperimen lebih tinggi daripada rata-rata hasil belajar siswa pada kelas kontrol. Pembelajaran dengan menggunakan model pembelajaran cooperative script membuat hasil belajar siswa menjadi lebih baik dan merupakan suatu inovasi dalam proses belajar mengajar di dalam kelas.

\section{Saran}

Dengan adanya hasil belajar siswa yang lebih baik ketika diajarkan dengan menggunakan model pembelajaran cooperative script, maka disarankan agar guru dalam proses belajar mengajar di dalam kelas hendaknya menggunakan model pembelajaran cooperative script untuk memperbaiki hasil belajar siswanya. Model pembelajaran cooperative script dapat diujicobakan untuk materi lain yang berhubungan dengan biologi atau materi lainnya.

\section{DAFTAR PUSTAKA}

Arimadona, S. (2017). Pengaruh Penerapan Model Pembelajaran Cooperative Learning Tipe STAD (Student Team Achievement Division) terhadap Hasil Belajar Biologi. JIPVA (Jurnal Pendidikan IPA Veteran), 1(1), 72-78.
Armansyah. (2014). Pengaruh Penerapan Model Pembelajaran Cooperative Script terhadap Hasil Belajar Siswa pada Mata Pelajaran Biologi Kelas $\mathrm{VIII}_{4}$ SMP Negeri 1 Makassar. Jurnal Nalar Pendidikan. 2(1), 66 71.

Baransano, A. Y., Yohanita, A. M., \& Damopolii, I. (2017). Penerapan Model Pembelajaran Picture And Picture untuk Meningkatkan Hasil Belajar Biologi Siswa Kelas XI IPA SMA YABT Manokwari. Seminar Nasional MIPA II Universita Papua "Konservasi, Matematika, Sains dan Teknologi" (hal. 273-280). Jakarta: Sinar Grafika.

Damopolii, I. (2018). Hubungan Motivasi Belajar dengan Hasil Belajar Biologi Siswa Di SMP 21 Rendani Manokwari. Disajikan pada Seminar Nasional dan Kongres HPPBI (pp. 1-5). Mataram: https://osf.io/4twg2.

Damopolii, I. (2017). Pengaruh Model Pembelajaran Kooperatif Tipe STAD Berbantuan Media Pembelajaran Komik IPA Terpadu terhadap Peningkatan Hasil Belajar Siswa. Prosiding Simposium Nasional MIPA (hal. 134-137). Makassar: Fakultas MIPA Universitas Negeri Makassar. (online) tersedia di: http://mipa.unm.ac.idmipaopen/Insar Damopolii_2017_08_05_09_00_1 76618.pdf

Damopolii, I., Nunaki, J. H., \& Supriyadi, G. (2018). Effect of Problem Solving Learning Model on Students Achievement. Journal of Educational Research and Evaluation, 2(1).

Chotimah, H., \& Dwitasari, Y. (2009). Strategi-strategi Pembelajaran untuk Penelitian Tindakan Kelas. Malang: Surya Pena Gemilang. 
Hanafiah, N dan Suhana, C. (2010). Konsep Strategi pembelajaran. Bandung: PT Refika Aditama.

Hestyana, A., Kistiyanto M. S., \& Puwanto. (2013). Pengaruh Model Pembelajaran Cooperative Script terhadap Hasil Belajar Geografi Kelas XI IPS di SMA Panjura Malang. Jurnal Pendidikan Geografi. 2(1). (online) tersedia di: http://jurnal-

online.um.ac.id/article/do/detailarticle/1/41/1555

Ibrahim, M. (2000). Pembelajaran Kooperatif. Surabaya: University Press.

Indriani, D. K., Tjandrakirana., \& Ibrahim, M. (2015). Pengembangan Perangkat Model Cooperative Scripts dalam Pembelajaran IPA untuk Meningkatkan Pemahaman Konsep IPA dan Keterampilan Berkomunikasi Siswa Di Sekolah Dasar. Jurnal Pendidikan Sains Pascasarjana Universitas Negeri Surabaya. 4(2), 495 - 502.

Muliawan, I. K., Syahruddin, H., \& Surajana, I. M. (2014). Pengaruh Model Pembelajaran Kooperatif Tipe Script dengan Siklus ACE terhadap Hasil Belajar Matematika Siswa Kelas V Sd Semester Genap Tahun Pelajaran 2013/2014 Di Gugus VIII Kecamatan Sukasada. e-Jurnal Mimbar PGSD Universitas Pendidikan Ganesha. 2(1).

Munir, M. K., Damopolii, I., \& Iwan. (2018). Pengaruh Model Pembelajaran Make a Match terhadap Hasil Belajar Siswa Di Kelas VII SMP Yapis Manokwari. KEGURU: Jurnal Ilmu Pendidikan Dasar, 2(1), 120-129.

Tiara, I., Sanjaya, S., \& Edi, R. (2014). Pengaruh Penerapan Model
Cooperative Script Terhadap Hasil Belajar Kimia Siswa Kelas X Sma Negeri 3 Tanjung Raja. Jurnal Penelitian Pendidikan Kimia, 1(2), 156-163.

Trianto, (2011). Mendesain Model Pembelajaran Inovatif - Progresif. Jakarta: Kencana.

Saragih, L. E., \& Tarigan, S. (2016). Perbedaan Hasil Belajar Siswa dengan Menggunakan Model Pembelajaran Kooperatif Script dan Problem Based Instruction pada Materi Pokok Sistem Ekskresi Manusia. Jurnal Pelita Pendidikan. 4(2).

Sharan, S. (2012). The Handbook of Cooperative Learning. Penerjemah: Drs. Marianto Samosir, S.H. Yogyakarta: Familia.

Slameto. (2013) Belajar dan FaktorFaktor Yang Mempengaruhi. Jakarta: Rineka Cipta.

Sugiyono. 2015. Metode Penelitian Kualitatif Kuantitatif dan $R \& D$. Bandung: Alfabeta.

Suprijono, A. (2013). Cooperative Learning Teori dan Aplikasi Paikem. Yogyakarta: Pustaka Pelajar.

Suryani, N. K., Atmaja, I. N. B., \& Natajaya, I, N. (2013) Pengaruh Model Pembelajaran Cooperative Script terhadap Hasil Belajar Sosiologi Ditinjau dari Motivasi Berprestasi Siswa Kelas X SMA PGRI 1 Amlapura. e-Journal Program Pascasarjana Universitas Pendidikan Ganesha Program Studi Administrasi Pendidikan, 4.

Suwardi, Y. P., Kistiyanto, M. S., \& Wagistina, S. (2013). Pengaruh Penerapan Model Pembelajaran Cooperative Script terhadap 
PENGARUH MODEL PEMBELAJARAN COOPERATIVE SCRIPT TERHADAP HASIL $\mid \mathbf{3 5}$

BELAJAR BIOLOGI DI KELAS VIII SMP 11 MANOKWARI

Yanto O. Rumbekwan, Aksamina M. Yohanita, Insar Damopolii

Kemampuan Berpikir Kritis dan Hasil Belajar Siswa Kelas X SMA Negeri 7 Malang. Jurnal Pendidikan Geografi. 2(1).

Werimon, S., Damopolii, I., \& Nunaki, J. H. (2017). Pengaruh Model Pembelajaran STAD Dipadu Media Pembelajaran Komik Materi Sistem Pencernaan Manusia terhadap Hasil Belajar Siswa. Jurnal Eksakta Pendidikan. 1(2). 33-4. 